\title{
ENVIRONMENTAL IMPACT ASSESSMENT OF FLOOD PROTECTION OBJECTS BASED ON RISK ANALYSIS IN SNAKOV VILLAGE SLOVAKIA
}

\author{
MARTINA ZELEŇÁKOVÁ ${ }^{1}$ \& LENKA ZVIJÁKOVÁ ${ }^{2}$ \\ ${ }^{1}$ Department of Environmental Engineering, Technical University of Košice, Vysokoškolská, Košice, Slovakia. \\ ${ }^{2}$ Euro Dotácie, a.s., Na Šefranici 8, Žilina, Slovakia.
}

\begin{abstract}
Due to the persistently high frequency of flood-related disasters, which are exacerbated by the on-going effects of climate change, the impacts of flooding on cities and towns can be devastating and deadly, resulting in the need to design and assessment of flood protection object (FPO). In their preparation, implementation, evaluation and authorization it is necessary to ensure consistent application of the environmental impact assessment (EIA). This paper explores the benefits of using the risk assessment/ analysis technique in the evaluation of FPO by examining the results of the EIA for a selected planned FPO in Slovakia. The methodology consists of three steps: identification, prediction and evaluation of the impacts of flood protection measures on the environment. Risk analysis (RA), based on determination of probability and consequences, is an appropriate tool to determine the level of the risk of the proposed flood mitigation measures and through which it is possible to choose the alternative with the lowest level of risk for the environment. This paper introduces an application of a new approach for risk assessment of actions in water management (FPO projects) using risk analysis method - universal matrix of risk analysis (UMRA) and matrix of qualitative and semi-quantitative assessment. Analysis and evaluation of environmental impacts of FPO in Snakov village on the environment prove that construction of polder is better alternative for flood protection of village than water course regulation. Keywords: Environmental impact assessment (EIA); Flood protection objects (FPO); Risk analysis $(R A)$; Universal matrix of risk analysis (UMRA).
\end{abstract}

\section{INTRODUCTION}

Environmental impact assessment (EIA), in principle, is the systematic approach used in the identification and evaluation of beneficial and harmful impacts on the physical, biological and socio-economic components of the environment, which may arise from the implementation of projects, plans, programs or policies (Gałaś [1], Morgan [2], Petts [3]; Wang et al. [4]). At present, EIA is a common feature in the appraisal of planned infrastructure projects (Tamura et al. [5]; Flyvbjerg [6]) such as roads (Zhou \& Sheate [7]), flood protection systems (Ludwig et al. [8]) and water supply systems (Al-Agha \& Mortaja [9]). Recent studies on climate change ([10-13]) indicated that countries will experience higher frequency of extreme flood events, creating greater demands for FPO. The impacts of flooding on cities and towns can be devastating and deadly, resulting in the need to design and assessment of flood mitigation measures ([14-16]). Planning of flood protection is a complex task, where many decisions must be taken about the protection concept, type of protection measures, design parameters, location, time of implementation etc. EIA is a necessary step during the early planning stages of FPO in order to gain clear insights of the structures' probable impacts with respect to the different components of the total environment.

\section{METHODS OF ASSESSMENT}

The process of the EIA is one of the most important instruments applied for environmental management (Gałaś [1]) firmly embedded in domestic and international environmental law 
(Morgan [2]). Perspectives regarding the methods in impact evaluation have evolved over the years of EIA practice. In the beginning of EIA methods typically denoted systematic approaches for identifying and integrating impact concerns; hence, they were seen as consisting of interaction matrices, networks, and checklists. Over time, methods have expanded to encompass scientific or policy tools or models which can be used to quantify, or at least descriptively address, the anticipated impacts of proposed actions on environmental media and resources (Canter [17]). The European Union has encouraged its members to apply risk assessment in EIA, particularly to extreme events such as floods are, but very little specific guidance is available on how to apply risk assessment in EIA (Lexer et al. [18]). The application of a risk-based approach early in the process should contribute to early identification of key issues which would become the focus of subsequent detailed assessment phases (EPA 2009). Zou et al. [19] applied a new model for comprehensive flood risk assessment based on set pair analysis and variable fuzzy sets theory, named set pair analysis-variable fuzzy sets model. Ji et al. [20] built a classification and regression tree model for the flood risk assessment which is able to extract the major impact factors from many complex variables, determine the factors' thresholds, and evaluate the levels of flood risk objectively. Methods also include decision analysis approaches (Levy [21]; Gałaś et al. [22]); for comparing and selecting a proposed action from several alternatives, monitoring for determining the effectiveness of mitigation measures (Su \& Tung [23]), and techniques for public participation (Canter [17]). One of the most effective methods used in the environmental impact assessment is the risk analysis - which is widely discussed in [32] and applied in the present study. Risk analysis (assessment) presents the probability of the consequences of the impacts, in our case the environmental impacts. The use of appropriate EIA techniques can aid the decisionmakers to formulate appropriate actions based on informed decisions in light of project urgency and limited resources, which are common constraints in the developing countries (Shah et al. [24]). Introducing risk analysis in decision making on environmental impacts of actions in water management can be a decisive issue for the design of project alternatives.

In the Slovakia, through Act of Law No. 24/2006 (The National Council of the Slovak Republic [25]) - a law that requires the assessment of proposed activities to determine its impacts on the "environment" - EIA is mandatorily being carried out on planned flood protection objects (FPO). According to Lexer et al. [18] and Zvijáková et al. [26] one way to advance the EIA system in the Slovakia is to develop method or guidance on how to apply risk assessment or analysis in EIA, that will provide better transparency to help maintain the impartiality of the entire process, the result of which should lead to the selection of future activity quantified with minimum risk to the environment. In the literature there are several other studies considering risk analysis in construction projects (Zavadskas et al. [27]). Risk analysis involving water constructions, especially FPO, is possible to find in Šauer et al. [28]; Zeleňáková et al. [29]; Gilbuena et al. [30]; Špačková et al. [31]; Zeleňáková and Zvijáková [32].

\section{RISK ANALYSIS}

The first element in the process of the risk analysis according to the proposed methodology consists of three activities: (1) identification, (2) prediction and (3) evaluation of impacts. Finally the decision making can be performed.

The aim of the first step - identification, for the purposes of impact assessment of the proposed activity on the environment, is to identify sources of risk areas (stressors) and their impact on the various components of the environment, including inhabitants. Our approach to identify potential risks to the environment (stressor effects on components of the 
environment) is to use a template for UMRA of the proposed activities related to water management, which is proposed in Table 1. Records are made by marking the box in which the potential risk occurs and then through detailed characteristics.

The second step - prediction of impacts - is based on the fact that there is a relationship between the proposed activity and the environment. These relationships can be described as a string of probabilities and consequences of stressor on environmental components. Probability is expressed as the possibility of adverse effects from exposure to stressors on environmental components. To determine the value of the probability " $P_{i}$ " of adverse effects as a result of exposure to the stressors impacts on various components of the environment, four levels of probability were chosen. For the determination of the probability " $P_{i}$ " $(0.25$ to

Table 1: UMRA for identification the environmental impacts of stressors.

\begin{tabular}{|c|c|c|c|c|c|c|c|c|c|c|c|c|c|c|}
\hline & FIEI & D OF Il & MPA & CT & & & & & & & & & & \\
\hline $\begin{array}{l}\text { STRESSOR } \\
\text { - SOURCE OF } \\
\text { RISK }\end{array}$ & 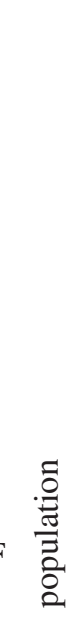 & 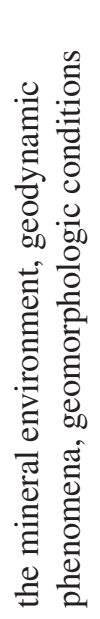 & 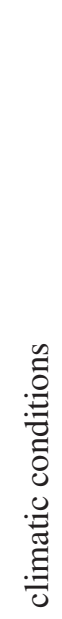 & 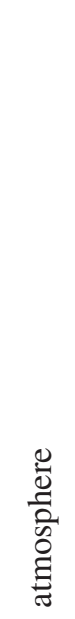 & 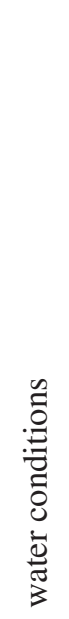 & $\overline{\bar{\delta}}$ & 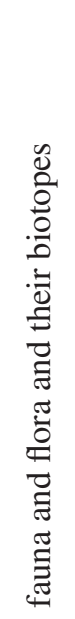 & 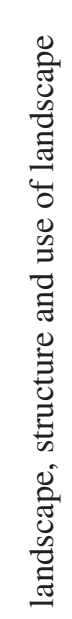 & 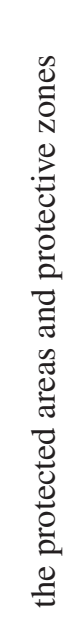 & 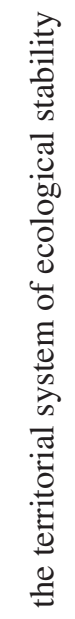 & 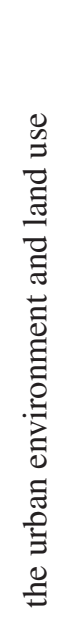 & 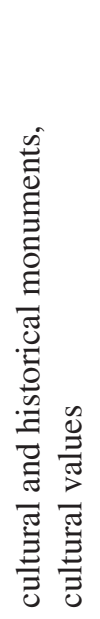 & 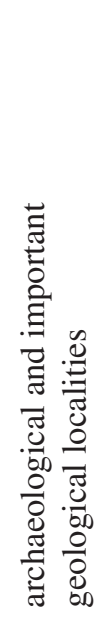 & $\frac{\check{\Phi}}{\check{0}}$ \\
\hline AIR & & & & & & & & & & & & & & \\
\hline $\begin{array}{l}\text { emission } \\
\text { WATER }\end{array}$ & $\bullet 1$ & & $\cdot 2$ & $\cdot 3$ & & & $\bullet 4$ & & $\cdot 5$ & & $\bullet 6$ & & & \\
\hline floods & $\cdot 7$ & & & & $\bullet 8$ & $\bullet 9$ & $\bullet 10$ & $\bullet 11$ & $\bullet 12$ & $\bullet 13$ & $\bullet 14$ & $\bullet 15$ & $\bullet 16$ & \\
\hline drought & & & $\bullet 17$ & & $\bullet 18$ & $\bullet 19$ & $\cdot 20$ & & & & & & & \\
\hline sediments & $\cdot 21$ & $\cdot 22$ & & & $\cdot 23$ & $\cdot 24$ & $\cdot 25$ & $\cdot 26$ & & & & & $\cdot 27$ & \\
\hline $\begin{array}{l}\text { pollutants } \\
\text { SOIL }\end{array}$ & $\cdot 28$ & $\cdot 29$ & & & $\cdot 30$ & & $\bullet 31$ & & $\cdot 32$ & & & & & \\
\hline erosion & & & $\cdot 33$ & $\cdot 34$ & $\cdot 35$ & $\cdot 36$ & & $\cdot 37$ & & & & & & \\
\hline landslides & $\cdot 38$ & $\cdot 39$ & & & $\bullet 40$ & $\bullet 41$ & $\bullet 42$ & $\bullet 43$ & $\bullet 44$ & & $\bullet 45$ & $\bullet 46$ & $\bullet 47$ & \\
\hline pollutants & $\cdot 48$ & & & & $\bullet 49$ & $\cdot 50$ & $\bullet 51$ & & & & $\cdot 52$ & & & \\
\hline $\begin{array}{l}\text { GENERAL } \\
\text { noise }\end{array}$ & $\cdot 53$ & & & & & & $\cdot 54$ & $\cdot 55$ & $\cdot 56$ & & & & & \\
\hline vibration & $\cdot 57$ & $\cdot 58$ & & & & & & & & $\cdot 59$ & & $\bullet 60$ & & \\
\hline waste & $\bullet 61$ & & & & $\cdot 62$ & $\cdot 63$ & $\bullet 64$ & & $\cdot 65$ & $\bullet 66$ & & & & \\
\hline radiation & $\bullet 67$ & & & & & & $• 68$ & & $\bullet 69$ & $\bullet 70$ & & & & \\
\hline
\end{tabular}


1), which enters into the calculation of the individual risk of each identified stressor effect on components of the environment, it is necessary to propose an indicator of probability (**) and different levels of criteria (*). Assessing the probability predicts the possibility of risk occurrence. Probability for qualitative risk assessment is most often expressed in the following terms: highly likely, likely, unlikely and highly unlikely. Impact occurs after exposure to a negative stressor on the individual components of the environment. The consequences of the adverse impact of the stressor must be examined at different levels. Four levels of stressor exposure to various components of the environment were chosen for determining the value of the consequence of " $C_{\mathrm{i}}$ ". To determine the value of the consequence " $C_{\mathrm{i}}$ " $(0.25$ to 1$)$, which enters into the calculation of the individual risk of each identified stressor impact on components of the environment, it is necessary to propose an indicator of consequence $(* *)$ and different levels of criteria $(*)$. The assessment of consequence defines a negative impact. For qualitative risk assessment impact is frequently expressed in the terms: marginal, small, medium or large. Four levels of probability and consequence were proposed based on the literature studied, such as by (Australian Government [35]) or (Department of Defense [36]).

For evaluation of impacts - the third step in risk analysis - the calculation of individual risk $R \mathrm{i}$ is required, which is done using the following equation (1):

$$
R_{i}=P_{i} \times C_{i}
$$

where $R \mathrm{i}$ is individual risk of each stressor impact on the component of the environment, $P \mathrm{i}$ is probability and $C \mathrm{i}$ is consequence.

The general methodology of the evaluation of the environmental impacts is presented in Fig. 1.

Risk index $I R_{\mathrm{j}}$ reflects what risk for the environment is posed by each proposed action. Index of risk $I R_{\mathrm{j}}$ is calculated using the following equation (2):

$$
I R_{j}=\sum_{j=1}^{n} P_{j} \times C_{i}
$$

where $I R$ is risk index, $P$ is probability, $C$ is consequence, $j$ is rank of the alternative, $n$ is number of considered impacts of stressors to environmental components $(n=1,2,3, \ldots, 70), i$ is rank of probabilities and consequences.

The data for the assessment were obtained from as much sources as was possible: literature, web pages, survey of the study area, discussions with the local people, and consultations with the experts.

The proposed methodology using risk analysis for determining the risks associated with the flood protection object and choosing the best alternative for the activity is applied to the flood protection object proposal in the village of Snakov.

\section{STUDY AREA}

Snakov village is situated in a valley where the river Topl'a rises, in its upper reaches, where the main valley ends and branching in the smaller valleys, near the Polish border. This village is situated in the western part of the Low Beskid (Nízke Beskydy) at an altitude of 450 meters. It belongs to the administrative district of Bardejov in Prešov region. Stream Vesna flows through the village, which rises near the border with Poland. The intense rains and storms cause flooding in village. The catchment belongs to Bodrog basin. Basic information's about the current state of the environment in the affected area was published by Zeleňáková et al. [33]. The total length of the proposed regulation of Vesna stream is a 1 $407.0 \mathrm{~m}$. In designing a trace of the river, as far as possible is used the tracing of the existing 


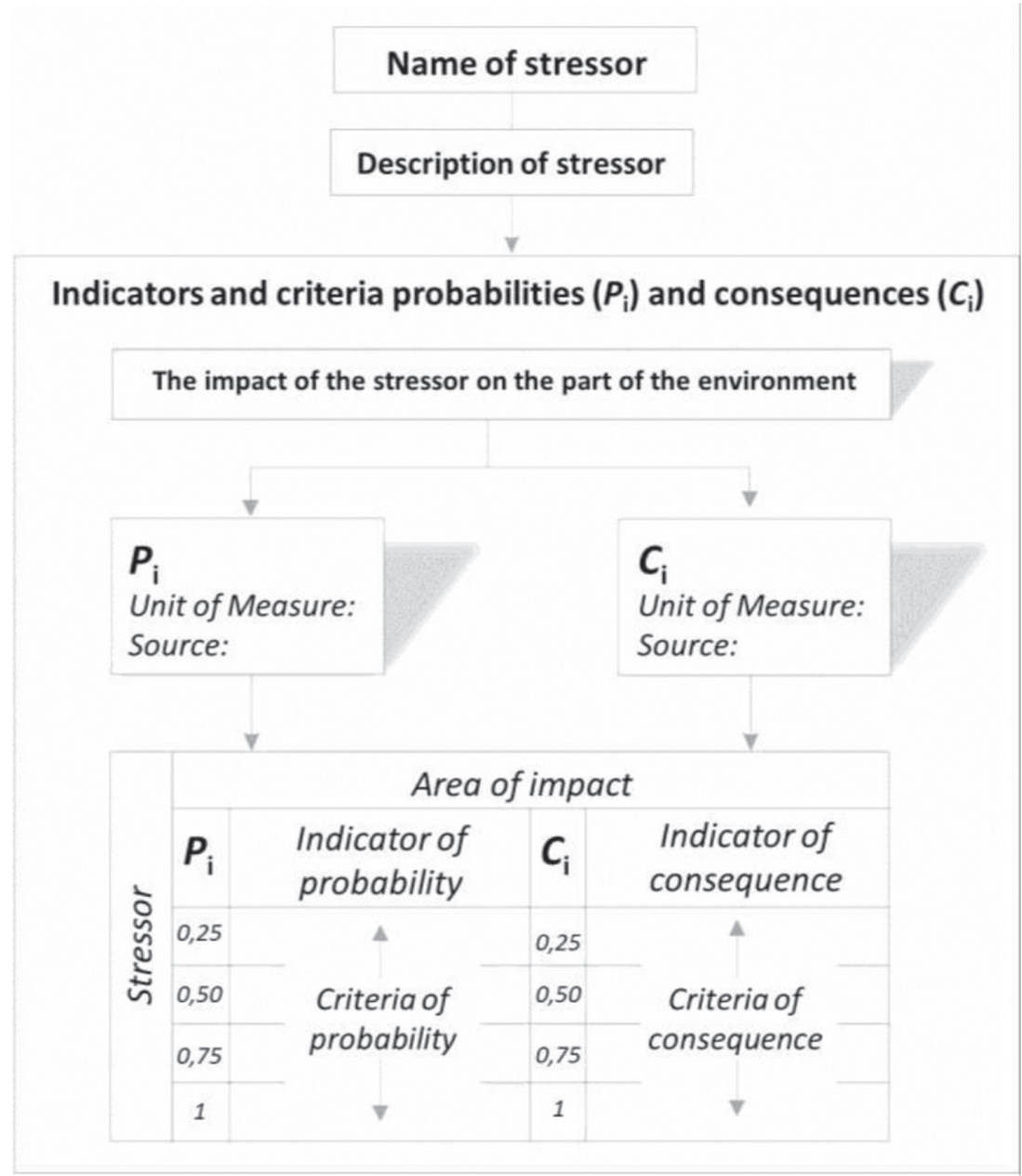

Figure 1: The methodology of the evaluation of impacts using risk analysis (source: authors).

river bed with accepting of nine small bridges at the stream. The purpose of the construction is to modify the flow profile of the stream Vesna in Snakov urban community in order to safely transfer a design flow Q100 $=28.0 \mathrm{~m}^{3} / \mathrm{s}$. The aim of this paper, based on research results, was to suggest the optimal variant of flood protection that would protect the inhabitants of Snakov and the surrounding environment from the consequences of torrential rain. The purpose of the proposed action (FPO) is to regulate runoff conditions in order to improve flood protection in the vicinity of the stream in Snakov. The proposed alternatives for proposed activity - FPO in Snakov are depicted at Figs. 2-4.

Alternatives are proposed so that the project's objectives can be feasibly met, in this case by adopting a different design for the project.

The impact of stressors on the environment were evaluated by risk analysis method separately for each proposed alternative AI and AII, including A0 (the current state of the area). 


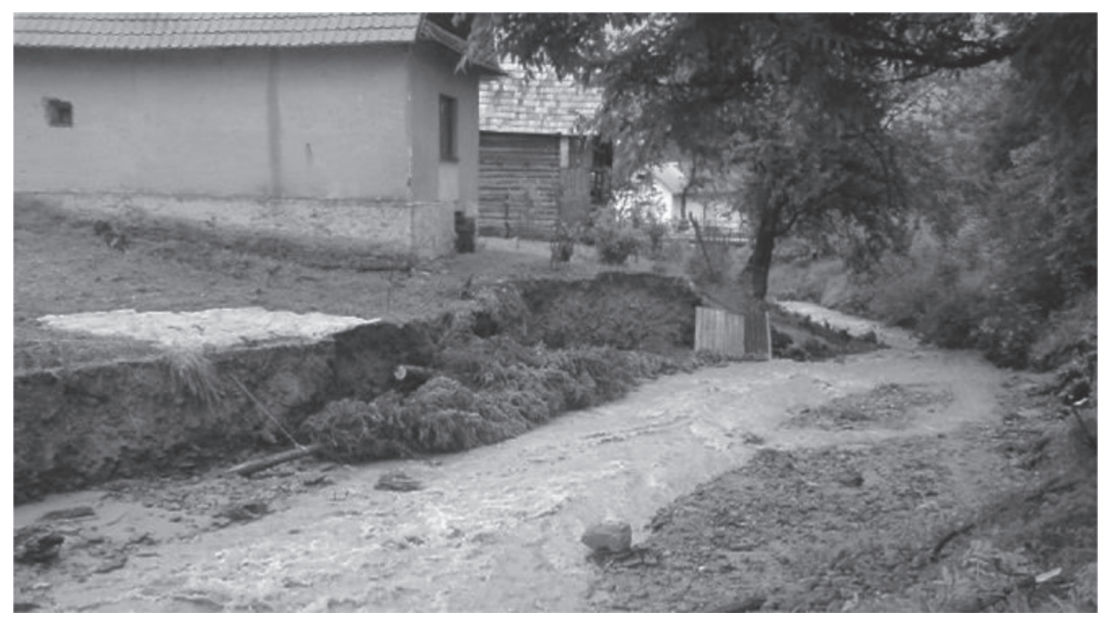

Figure 2: Alternative $0(\mathrm{~A} 0)$ : stream bed will not be regulated - the current state (photo: June 2010, flood).

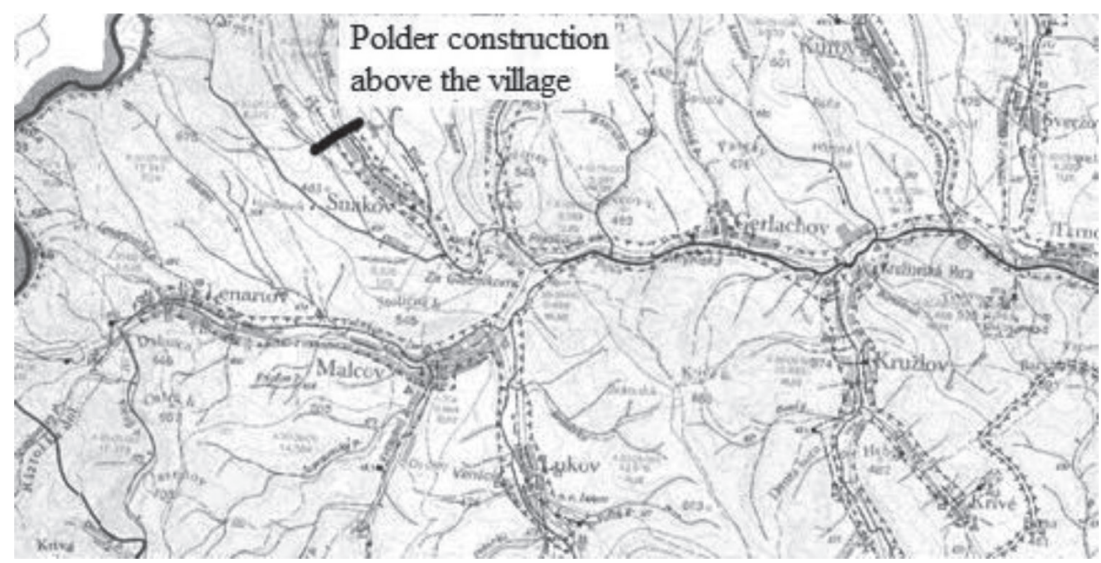

Figure 3: Alternative I (AI): stream bed will be regulated and a polder will be constructed above the village (source: authors).

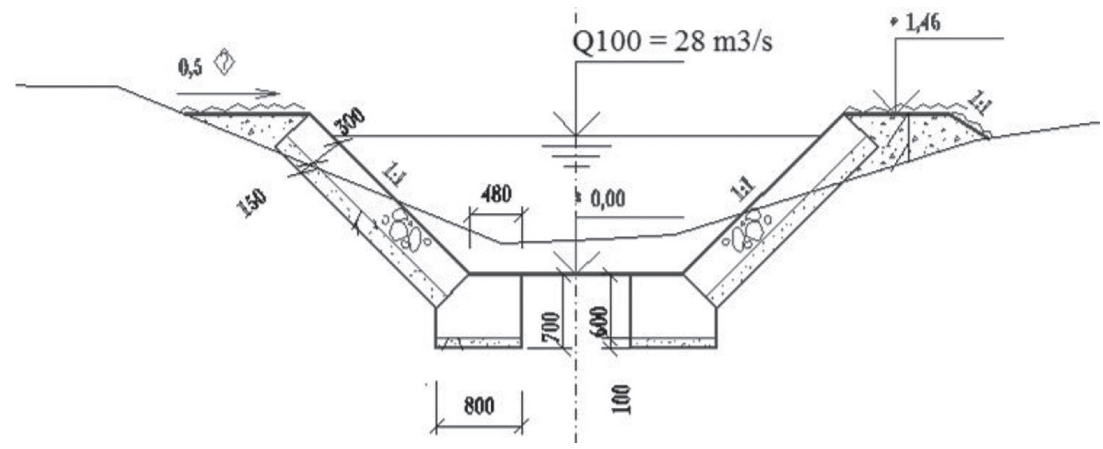

Figure 4: Alternative II (AII): stream bed in the village will be regulated for Q100 (source: authors). 


\section{RESULTS AND DISCUSSION}

All stressors that have impacts on components of the environment during the activity - construction of flood protection object and their probabilities of occurrence and the consequences were assessed according to Zeleňáková et al. [33] and Zvijáková \& Zeleňáková [34]. Chosen impacts of stressors based on Tab. 1 (impact of emissions on the population, as an example, according to the number of stressor) are presented in Table 2. For each of the assessed variants of the proposed activity of flood protection in the village Snakov the probability $P_{\mathrm{i}}$ and consequence $C_{\mathrm{i}}$ is stated. The proposal reflects also consultations with experts and professionals in the field of water management and environment protection.

Table 2: Impacts of chosen stressors on components of the environment for the considered variants of the proposed action $\mathrm{A}_{\mathrm{j}}(\mathrm{A} 0, \mathrm{AI}, \mathrm{AII})$ and risk calculation.

\begin{tabular}{|c|c|c|c|c|c|}
\hline & $\begin{array}{l}\text { Impact of } \\
\text { stressors on } \\
\text { components of } \\
\text { the environment }\end{array}$ & $\begin{array}{l}\text { Determination of } \\
\text { probabilities }\end{array}$ & $\begin{array}{l}\text { Determination of } \\
\text { consequences }\end{array}$ & $\begin{array}{l}\text { Calculation } \\
\text { of risk }\end{array}$ & $\begin{array}{l}\text { Alterna- } \\
\text { tive }\end{array}$ \\
\hline \multirow[t]{4}{*}{1} & $\begin{array}{l}\text { Impact of } \\
\text { emissions on }\end{array}$ & $\begin{array}{ll}\mathrm{P}_{1} & \begin{array}{l}\text { Burdening by } \\
\text { pollutants (-) }\end{array}\end{array}$ & $\begin{array}{ll}\mathrm{C}_{1} & \begin{array}{l}\text { Health effects of } \\
\text { emissions (-) }\end{array}\end{array}$ & $\mathrm{R}_{1}=\mathrm{P}_{1} \times \mathrm{C}_{1}$ & $\mathrm{Aj}$ \\
\hline & the population & 0.25 minimal & 0.25 none & 0.0625 & A0 \\
\hline & & 0.25 minimal & 0.75 toxic & 0.1875 & AI \\
\hline & & 0.25 minimal & 0.5 irritation & 0.125 & AII \\
\hline \multirow[t]{4}{*}{7} & $\begin{array}{l}\text { Impact of flood- } \\
\text { ing on water } \\
\text { conditions }\end{array}$ & $\begin{array}{cl}\mathrm{P}_{7} & \text { Number of an- } \\
& \text { nouncements } \\
& \text { of highest level } \\
& \text { of flooding (per } \\
& \text { year) (-) }\end{array}$ & $\begin{array}{c}\mathrm{C}_{7} \text { Capacity flow } Q_{\mathrm{n}} \\
\left(\mathrm{m}^{3} \cdot \mathrm{s}^{-1}\right)\end{array}$ & $\mathrm{R}_{7}=\mathrm{P}_{7} \times \mathrm{C}_{7}$ & $\mathrm{Aj}$ \\
\hline & & $0,5 \quad 2-3$ & $1 \leq \mathrm{Q}_{50}$ & 0.5 & $\mathrm{~A} 0$ \\
\hline & & $0,5 \quad 2-3$ & $0.5=Q_{100}$ & 0.25 & AI \\
\hline & & $0.52-3$ & $0.25^{3} \mathrm{Q}_{100}$ & 0.125 & AII \\
\hline \multirow{4}{*}{\multicolumn{2}{|c|}{$\begin{array}{l}38 \text { Impact of land- } \\
\text { slides on the } \\
\text { population }\end{array}$}} & $\begin{array}{ll}\mathrm{P}_{38} & \text { Occurrence of } \\
& \text { slope deforma- } \\
\text { tions in the } \\
\text { study area }(n)\end{array}$ & $\begin{array}{c}\mathrm{C}_{38} \\
\begin{array}{l}\text { Socio-economic } \\
\text { significance }(-)\end{array}\end{array}$ & $\begin{array}{l}\mathrm{R}_{38}=\mathrm{P}_{38} \times \\
\mathrm{C}_{38}\end{array}$ & $\mathrm{Aj}$ \\
\hline & & $0.51-20$ & 0.5 medium & 0.25 & A0 \\
\hline & & $0.51-20$ & 0.25 small & 0.125 & AI \\
\hline & & $0.51-20$ & 0.25 small & 0.125 & AII \\
\hline \multirow{4}{*}{\multicolumn{2}{|c|}{$\begin{array}{l}53 \text { Impact of noise } \\
\text { on the popula- } \\
\text { tion }\end{array}$}} & 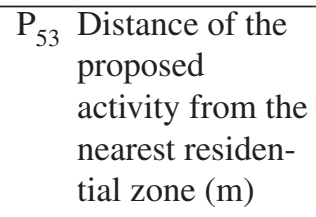 & $\begin{array}{l}\mathrm{C}_{53} \text { Health effects of } \\
\text { noise (-) }\end{array}$ & $\begin{array}{l}\mathrm{R}_{53}=\mathrm{P}_{53} \times \\
\mathrm{C}_{53}\end{array}$ & $\mathrm{Aj}$ \\
\hline & & 0.251000 .1 & 0.25 neutral & 0.0625 & $\mathrm{~A} 0$ \\
\hline & & $0.7510 .1-100.0$ & 0.5 disturbing & 0.375 & AI \\
\hline & & $0.7510 .1-100.0$ & 0.5 disturbing & 0.375 & AII \\
\hline
\end{tabular}


An example of "Determination of probabilities" and "Determination of consequences" for stressor (related to air -1 ) is in the Table 3. The indicator of the probability is selected according to the degree of air pollution based on the exceeding of the limit concentration values, which are included in the map of air pollution of Slovakia, Fig. 5, by MoE, SAE [37]. Classification of air pollution in Table 3: minimal, moderate, medium, high and very high is our criteria for four levels of probability, for $P_{1}$ - impact of emissions on the population.

An indicator of consequences was chosen the intended adverse health effects of emissions on human health, which can be characterized for purposes of this assessment by Soják [38] also in four classes as:
a. none effect;
b. mechanical - irritate eye conjunctival sac, mucous membranes, lymphatic vessels in the lungs;
c. toxic - can contain toxic chemicals, metals; long term exposure to the high concentration of $\mathrm{SiO}_{2}$ leads to silicosis;
d. allergenic - biological aerosols, certain chemicals and metals; and / or carcinogenic - certain chemicals and metals, asbestos, carbon black.

Table 3: Probability and consequence of emissions on population

\begin{tabular}{|c|c|c|c|c|}
\hline \multirow{6}{*}{ 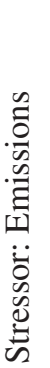 } & \multicolumn{4}{|c|}{ Impact on population } \\
\hline & $P_{1}$ & $\begin{array}{l}\text { Classification of air } \\
\text { pollution (-) }\end{array}$ & $C_{1}$ & $\begin{array}{l}\text { Health consequences of } \\
\text { emissions (point) }\end{array}$ \\
\hline & 0.25 & Minimal & 0.25 & a. \\
\hline & 0.5 & Moderate & 0.5 & b. \\
\hline & 0.75 & Medium & 0.75 & c. \\
\hline & 1 & high, very high & 1 & d. \\
\hline
\end{tabular}

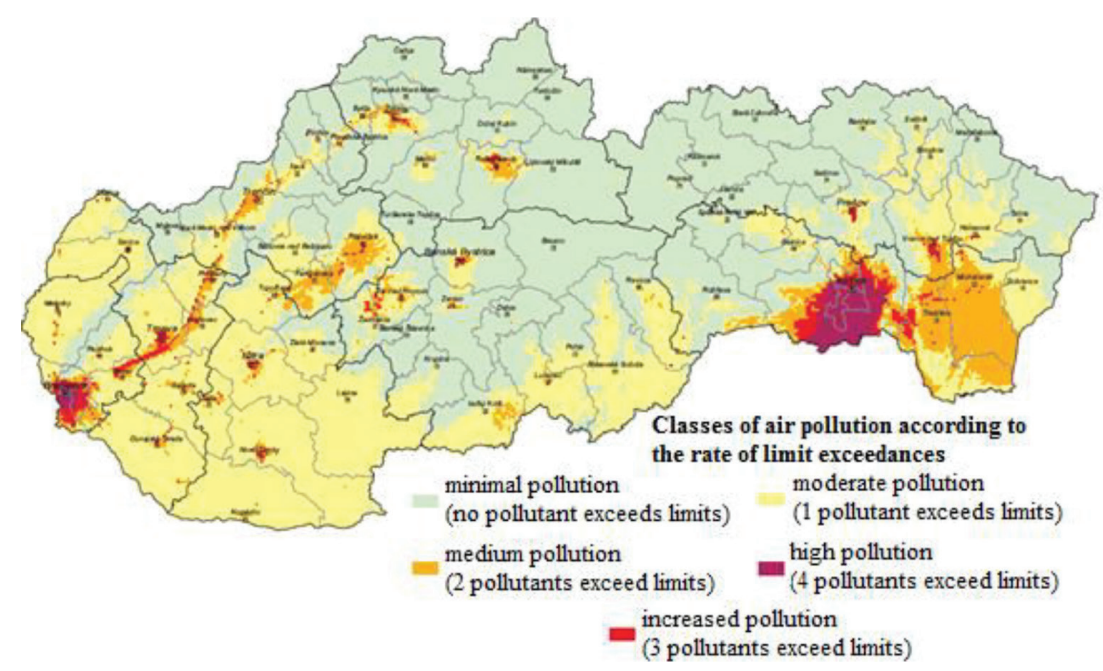

Figure 5: Air pollution in the Slovak Republic by MoE, SAE [37]. 
These health effects of emissions in Table 3 are classified into four levels due to $C_{1}$.

An another example [39] of "Determination of probabilities" and "Determination of consequences" for stressor (related to water -7 ) is in the Table 4.

The local potential for flooding was state according the Fig. 6.

Direct and indirect health effects of flooding are determined by point classifiaction according to Table 5 (arranged according to Koppová 2011). Assessor assigns one point for each consequence. The sum of points is indicator of health consequences of flooding.

The other impacts of stressors on compounds of the environment (70 stressors from Table 1) are stated similarly, based on Zvijáková and Zeleňáková [34].

For the purpose of the proposed action assessment, it is finally important to determine the level of risk which arises from the action of each stressor on the individual components of the environment as a consequence of the activity.

In Table 2 risks $R \mathrm{i}$ are calculated individually for each stressor which has an impact on air for each considered alternative for determination of risk index $I R_{\mathrm{j}}$. Similarly, risk of all other stressors which has an impact on the components of the environment were calculated. The application shows that the impacts of stressors on components of the environment achieve different levels of risk in the environment. Table 6 shows the number of stressors that achieve different levels of risk for each assessed alternative.

Table 4. Probability and consequence of flooding on population.

\begin{tabular}{|c|c|c|c|c|}
\hline \multirow{6}{*}{ 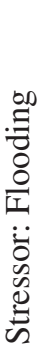 } & \multicolumn{4}{|c|}{ Impact on population } \\
\hline & $P_{1}$ & $\begin{array}{l}\text { Local potential for } \\
\text { flooding (-) }\end{array}$ & $C_{1}$ & $\begin{array}{l}\text { Health consequences of } \\
\text { flooding (point) }\end{array}$ \\
\hline & 0.25 & very low, low & 0.25 & 0 \\
\hline & 0.5 & medium & 0.5 & $1-2$ \\
\hline & 0.75 & high & 0.75 & $3-4$ \\
\hline & 1 & very high & 1 & 35 \\
\hline
\end{tabular}

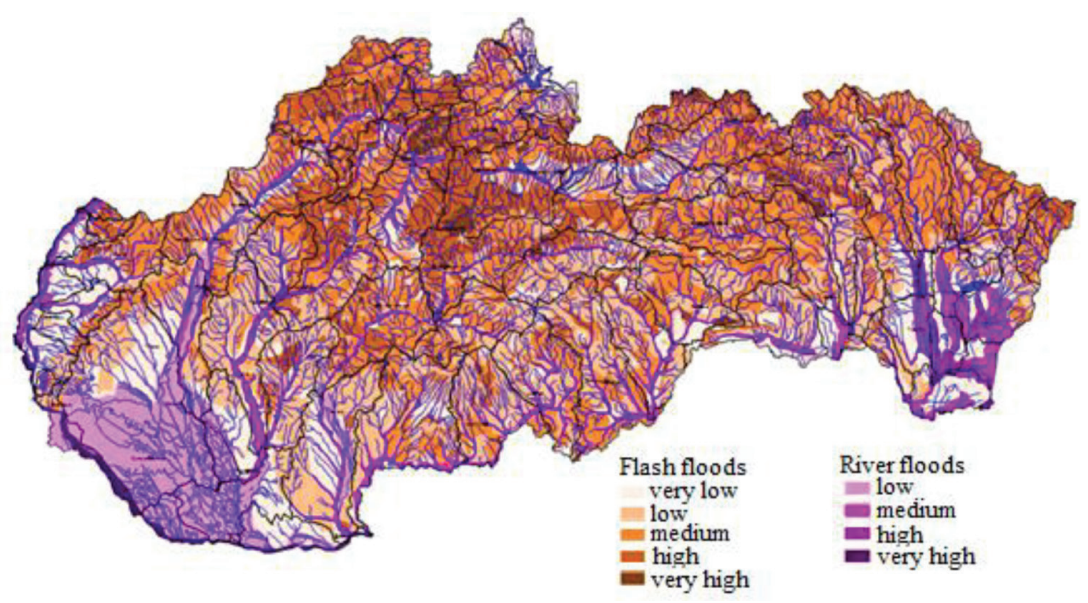

Figure 6: Potential of flooding in the Slovak Republic. 
Table 5: Probability and consequence of flooding on population.

\begin{tabular}{|c|c|c|}
\hline Health risks & Direct health effects & Point \\
\hline Loss of lives & Death as a consequence of flood. & \\
\hline Injury & Injury as a consequence of flood. & \\
\hline Exposure to polluted water & Infections of the skin, nose, ear, eye. & \\
\hline Exposure to cold water & Shock, cardiac arrest, hypothermia. & \\
\hline Excessive stress & $\begin{array}{l}\text { Physical and mental exhaustion of the } \\
\text { body. }\end{array}$ & \\
\hline Health risks & Indirect health effects & Point \\
\hline Contamination of drinking water & $\begin{array}{l}\text { Diseases - hepatitis A, dysentery, ty- } \\
\text { phoid, other bacterial and viral diseases. }\end{array}$ & \\
\hline Contamination of food and crops & $\begin{array}{l}\text { Infectious diseases and intoxication by } \\
\text { chemicals. }\end{array}$ & \\
\hline Leakage of chemicals & Acute intoxication by chemicals. & \\
\hline The dumping of waste & Infectious diseases, skin affections. & \\
\hline Overgrowth of mosquitoes & Infectious diseases. & \\
\hline $\begin{array}{l}\text { Migration of animals, mainly } \\
\text { rodents. }\end{array}$ & $\begin{array}{l}\text { Infectious diseases (leptospirosis, tula- } \\
\text { remia, toxoplasmosis, etc.). }\end{array}$ & \\
\hline $\begin{array}{l}\text { Humid residential areas exposed } \\
\text { to mold }\end{array}$ & $\begin{array}{l}\text { Acute and chronic respiratory diseases, } \\
\text { sensitization, allergies. }\end{array}$ & \\
\hline $\begin{array}{l}\text { Food shortages, disruption of } \\
\text { rescue system. }\end{array}$ & Threat to health and life. & \\
\hline $\begin{array}{l}\text { Increased psychological stress and } \\
\text { social exclusion }\end{array}$ & Increase in mental disorders. & \\
\hline Lack of health services & Threat to health and life. & \\
\hline
\end{tabular}

Table 6: Number of stressors that achieve different levels of risk for each alternative.

\begin{tabular}{lllll}
\hline \multirow{2}{*}{ Level } & Characteristics & Alternative $(\mathrm{Aj})$ & \\
\cline { 3 - 5 } & A0 & AI & AII \\
\hline 1 & Negligible $R_{\mathrm{i}}=(0-0.125)$ & 40 & 40 & 40 \\
2 & Low $R_{\mathrm{i}}=(0.126-0.25)$ & 15 & 23 & 18 \\
3 & Medium $R_{\mathrm{i}}=(0.26-0.5)$ & 7 & 6 & 9 \\
4 & High $R_{\mathrm{i}}=(0.51-1)$ & 8 & 1 & 3 \\
\hline
\end{tabular}

For Alternative 0 the high risk to the environment lies in impacts of stressors with the ID: $7,8,9,10,18,23,35$ and 40. For Alternative I high risk of environmental impact lies in sediments to water ratios with ID 23. For Alternative II, these impacts of stressors present high risk for the environment: 34,55 and 58 . 
Table 7: Final risk assessment.

\begin{tabular}{lll}
\hline Risk index $I R_{\mathrm{j}}(-)$ & Category & $\begin{array}{l}\text { Degree of risk of the proposed } \\
\text { activity for the environment }\end{array}$ \\
\hline $4.375-15$ & $\mathrm{IV}^{\text {th }}$ & very low \\
$15.01-25$ & $\mathrm{III}^{\mathrm{rd}}$ & low \\
$25.01-40$ & $\mathrm{II}^{\text {nd }}$ & medium \\
$40.1-70$ & $\mathrm{I}^{\text {st }}$ & high \\
\hline
\end{tabular}

According to equation (2) the values of $I R_{\mathrm{j}}$ (risk index) for assessed variants are calculated as follows. For:

- Alternative 0 has a value of $I R_{0}=15.75$;

- Alternative I has a value of $I R_{\mathrm{I}}=14.3125$ and

- Alternative II has a value of $I R_{\mathrm{II}}=15.25$.

It means that Alternative I presents the lowest risk for the environment.

Calculation of the risk index $I R_{\mathrm{j}}$ determines the risk for the environment posed by water structures. It is directly related to the environmental impact assessment of activities under Law No. 24/2006 Coll in Slovakia. Under this law it is necessary to compare alternatives for the proposed activity and produce a proposal for the optimum alternative. According to the numerical value of the risk index $I R_{\mathrm{j}}$ the variants of the proposed activities are assessed and classified into one of four proposed categories according to Table 7.

It can be seen from this assessment that different values of risk index $I R_{\mathrm{j}}$ are obtained for each of the assessed variants, and they fall into two risk categories. The numerical values of risk index $I R_{\mathrm{j}}$ for the assessed variants of the proposed activity place them either in following categories:

- Alternative 0 - "Current state" - IIII ${ }^{\text {rd }}$ category, low risk for the environment;

- Alternative 1 - "Construction of polder" - IV ${ }^{\text {th }}$ category, very low risk for the environment;

- Alternative 2 - "Water course regulation" - III ${ }^{\text {rd }}$ category, low risk for the environment.

The aim of the work is to improve existing qualitative and quantitative methods for assessing the impacts of proposed activities on the environment. Innovation is presented by an implementation of universal matrix of risk analysis for flood mitigation measures and its application in study area endangered by floods.

\section{CONCLUSIONS}

We try to enhance environmental safety, ensuring suitability, strength, usability and aesthetics of our environment by legal, educational, economic, organizational and other instruments. These include also the construction of flood mitigation measures in parts of Slovakia which are in existing or potential flood risk areas. For the planning authorities it is necessary draw up information about the possible environmental impacts of development actions. One of the tools available to satisfy this need is represented by the procedure of EIA. In traditional EIA a restricted or biased assessment of alternatives in the first stages might cause EIA to 
fail as a tool to help decision makers find the best alternative. Effects on the environment should be taken into account at the earliest possible stage in all the technical planning and decision-making processes. Introducing risk analysis in decision making on environmental impacts of actions in water management can be a decisive issue for the design of project alternatives.

We introduce a system of environmental impact assessment of water constructions through risk analysis evaluation of options, the result of which should lead to the selection of future activity quantified with minimum risk to the environment. EIA is information and knowledge dependent - knowledge about environmental values that may be at risk from proposed development, knowledge about the nature, extent and duration of risks to which those environmental values may be exposed, knowledge about what can be done to prevent, avoid or mitigate those risks and identify opportunities, and knowledge about whether those identified risks were indeed controlled [32]. Risk assessment is an effective tool to be used in EIA. The proposed methodology is applied to a flood protection object proposal in village of Snakov in the north-eastern part of Slovakia. The village has constant problems with floods, which cause damage and have adverse consequences for human health, the environment and personal and municipal property. Comparison of variants and designation of the optimal variant is implemented based on selected criteria which objectively describe the characteristic features of the planned variants and their impact on the environment. The proposed methodology is intended to improve the outcome of the EIA and may also find application in other infrastructure projects. On the basis of the assessment we may justify the proposal as follows: the result of the comparison of alternatives for the proposed action - FPO in the village Snakov at the stream Vesna is that the three considered alternatives (Alternative 0, Alternative I and Alternative II) are placed on the basis of the calculated risk index $I R_{\mathrm{j}}$ into two different categories $\left(\mathrm{IV}^{\text {th }}\right.$ or $\mathrm{III}^{\mathrm{rd}}$ ) of environmental risk. Based on the risk index $I R_{\mathrm{j}}$ we can state that Alternative I is optimal in the light of expected environmental impacts, and therefore it is recommended to regulate the Slatvinec watercourse through Snakov and build the polder above the village. The flood protection object, the proposed activity, according to Table 9 is assigned to the $\mathrm{IV}^{\text {th }}$ category of water structure, which was designated based on the calculated risk index and presents a very low level of risk to the environment.

The work points out the possibility of improving existing methods of assessing the impacts of proposed activities by applying risk analysis in assessing the impact of water structures on the environment.

\section{ACKNOWLEDGMENTS}

This paper was written thanks to support from project VEGA 1/0278/18.

\section{REFERENCES}

[1] Gałaś, S., Assessment of the quality of the environment in the V4 countries. Krakow: AGH University of Science and Technology Press, 2014.

[2] Morgan, R.K., Environmental impact assessment: the state of the art. Impact Assessment and Project Appraisal, 30, pp. 5-14, 2012. https://doi.org/10.1080/14615517.2012.661557

[3] Petts, J., Handbook of Environmental Impact Assessment, vol. I. London: Blackwell Science, pp. 3-11, 1999. 
[4] Wang, Y.M., Yan, J.B. \& Xu, D.L., Environmental impact assessment using evidential reasoning approach. European Journal of Operational Research, 174, pp. 1885-1913, 2006.

https://doi.org/10.1016/j.ejor.2004.09.059

[5] Tamura, H., Fujita, S. \& Koi, H., Decision analysis for environmental impact assessment and consensus formation among conflicting multiple agents. Science of the Total Environment, 153, pp. 203-210, 1994.

https://doi.org/10.1016/0048-9697(94)90199-6

[6] Flyvbjerg, B., Policy and planning for large-infrastructure projects: problems, causes, cures. Environment and Planning B: Planning and Design, 34, 578-597, 2007. https://doi.org/10.1068/b32111

[7] Zhou, K. \& Sheate, W.R., EIA application in China's expressway infrastructure: clarifying the decision-making hierarchy. Journal of Environmental Management, 92 , pp. 1471-1483, 2011. https://doi.org/10.1016/j.jenvman.2010.12.011

[8] Ludwig, H.F., Gunartnam, D. \& Yuming, S., Environmental impact assessment for Xiaolangdi Yellow River multi-purpose economic-cum-environmental improvement project. Environmentalist, 15, pp. 45-57, 1995. https://doi.org/10.1007/bf01888889

[9] Al-Agha, M.R. \& Mortaja, R.S., Desalination in the Gaza Strip: drinking water supply and environmental impact. Desalination, 173, pp. 157-171, 2005. https://doi.org/10.1016/j.desal.2004.06.212

[10] EC (European Commission), Regions 2020. The climate change challenge for European regions. Brussels. 2009.

[11] Pollner, J., Kryspin-Watson, J. \& Nieuwejaar, S., Disaster Risk Management and Climate Change Adaptation in Europe and Central Asia. Washington: WB, 2010.

[12] EPA (Environmental Protection Authority), Review of the Environmental Impact Assessment Process in Western Australia. Perth, Western Australia, 2009.

[13] Kundzewicz, Z.W., et al., Flood risk and climate change: global and regional perspectives. Hydrological Sciences Journal, 59, pp. 1-28, 2014. https://doi.org/10.1080/02626667.2013.857411

[14] Korytárová, J., Šlezingr, M. \& Uhmannová, H., Determination of potential damage to representatives of real estate property in areas afflicted by flooding. Journal of Hydrology and Hydromechanics, 55, pp. 282-228, 2007.

[15] Li, G.F., Xiang, X.Y., Tong, Y.Y. \& Wang, H.M., Impact assessment of urbanization on flood risk in the Yangtze River Delta. Stochastic Environmental Research and Risk Assessment, 27, pp. 1683-1693, 2013. https://doi.org/10.1007/s00477-013-0706-1

[16] Hanák, T. \& Korytárová, J., Risk zoning in the context of insurance: comparison of flood, snow load, windstorm and hailstorm. Journal of Applied Engineering Science, 12, pp. 137-144, 2014. https://doi.org/10.5937/jaes12-6098

[17] Canter, L.W., Methods for Effective Environmental Information Assessment (EIA) Practice. In: AEPI. Environmental Methods Review: Retooling Impact Assessment for the New Century. 1998. 
[18] Lexer, W., Paluchova, K. \& Schwarzl, B., Risk Assessment. IMProving the IMPlementation of Environmental IMPact Assessment 3 Risk Assessment D 3.2 Report WP 3. Vienna: Österreichisches Institut für Raumplanung, 2006.

[19] Zou, Q., Zhou, J., Zhou, Ch., Song, L. \& Guo, J., Comprehensive flood risk assessment based on set pair analysis-variable fuzzy sets model and fuzzy AHP Stochastic Environmental Research and Risk Assessment, 27, pp. 525-546, 2012.

https://doi.org/10.1007/s00477-012-0598-5

[20] Ji, Z., Li, N., Xie, W., Wu, J. \& Zhou, Y., Comprehensive assessment of flood risk using the classification and regression tree method. Stochastic Environmental Research and Risk Assessment, 27, pp. 1815-1828, 2013.

https://doi.org/10.1007/s00477-013-0716-z

[21] Levy, J.K., Multiple criteria decision making and decision support systems for flood risk management. Stochastic Environmental Research and Risk Assessment, 19, pp. 438-447, 2005. https://doi.org/10.1007/s00477-005-0009-2

[22] Gałaś, S., Gałaś, A., Zeleňáková, M., Zvijáková, L., Fialová, J., Kubičková, H., Environmental impact assessment in the Visegrad Group countries. Environmental Impact Assessment Review, 55, pp. 11-20, 2015. https://doi.org/10.1016/j.eiar.2015.06.006

[23] Su, H.T. \& Tung Y.K., Multi-criteria decision making under uncertainty for flood mitigation. Stochastic Environmental Research and Risk Assessment, 27, pp. 1815-1828, 2014.

[24] Shah, A., Salimullah, K., Sha, M.H., Razaulkah, K. \& Jan I.F., Environmental impact assessment (EIA) of infrastructure development projects in developing countries. International Journal of Sustainable Development, 1, pp. 47-54. 2010.

[25] The National Council of the Slovak Republic. Act of Law No. 24/2006 from December 14th 2005 on Environmental Impact Assessment and its amendments.

[26] Zvijáková, L., Zeleňáková, M. \& Purcz, P., Evaluation of environmental impact assessment effectiveness in Slovakia. Impact Assessment and Project Appraisal, 32, pp. 150 $161,2014$. https://doi.org/10.1080/14615517.2014.893124

[27] Zavadskas, E.K., Turskis, Z. \& Tamošaitienè, J., Risk assessment of construction projects. Journal Civil Engineering and Management, 16, pp. 33-46, 2010. https://doi.org/10.3846/jcem.2010.03

[28] Šauer, P., Kreuz, J., Hadrabová, A. \& Dvořák, A., Assessment of environmental policy implementation: two case studies from the Czech Republic. Polish Journal of Environmental Studies, 21, pp. 1383-1391, 2012.

[29] Zeleňáková, M., Gałaś, S., Zvijáková, L. \& Šlezingr, M., Calculation of risk posed by flood protection measures as part of the environmental impact assessment process. Polish Journal of Environmental Studies, 21, pp. 459-463, 2012.

[30] Gilbuena, Jr.R., Kawamura, A., Medina, R., Amaguchi, H., Nakagawa, N. \& Du Bui D., Environmental impact assessment of structural flood mitigation measures by a rapid impact assessment matrix (RIAM) technique: A case study in Metro Manila, Philippines. Science of the Total Environment, 456-457, pp. 137-147, 2013. https://doi.org/10.1016/j.scitotenv.2013.03.063 
[31] Špačková, O., Straub, D. \& Rimböck A., How to select optimal mitigation strategies for natural hazards? In: 11th International Conference on Structural Safety \& Reliability ICOSSAR 2013, Columbia University, NY, 2013.

[32] Zeleňáková, M. \& Zvijáková, L., Using Risk Analysis for Flood Protection Assessment Springer International Publishing, Hardcover ISBN 978-3-319-52149-7 2017.

[33] Zeleňáková, M., Sarka, D. \& Zvijáková, L., Snakov - flood mitigation measures in the village. Preliminary environmental study, worked out according to Law No. 24/2006 Z. z. on environmental impact assessment, Košice, 2011.

[34] Zvijáková, L. \& Zeleňáková, M., Risk analysis in the process of on environmental impact assessment of flood protection objects (in Slovak), Prague: Leges, 2015.

[35] Australian Government, Risk Analysis Framework. Australia: Commonwealth of Australia, 2005.

[36] Department of Defense, Standard practice for system safety, MIL-STD-882D, USA: Department of Defense, 2000.

[37] MoE (Ministry of the Environment), SAE (Slovak Agency of the Environment) Environmental regionalization of the Slovak Republic (Environmentálna regionalizácia Slovenskej republiky) (in Slovak), [online]. Bratislava: MoE SR, Košice: SAE, 2010 [cit. 2016-02-14]. Available at: http://www1.enviroportal.sk/clanok.php?cl=14075

[38] Soják, L. et al, Monitoring of contamination of the environment (Monitoring kontaminácie životného prostredia) (in Slovak) [online]. Bratislava: Commenius University, 2002 [cit. 2016-05-11]. Available at: http://www.fns.uniba.sk/uploads/media/Monitoring_ kontaminacie_zivotneho_prostredia.pdf

[39] Zvijáková, L. \& Zeleňáková, M., Environmental impact assessment of structural flood mitigation measures: a case study in Siba, Slovakia. Environmental Earth Sciences, 75, pp. 1-10, 2016.

https://doi.org/10.1007/s12665-016-5646-x 